\title{
Optimasi Komposisi Pakan Ayam Broiler Sesuai Standarisasi Kebutuhan Nutrisi Menggunakan Algoritma Genetika
}

\author{
Anas Abiem Bahar \\ Teknologi Informasi \\ Politeknik Negeri Jember \\ Jember, Indonesia \\ abiemaassyikin@gmail.com \\ Firdaustinovida Aisyah \\ Teknologi Informasi \\ Politeknik Negeri Jember \\ Jember, Indonesia \\ firdaaisyah22@gmail.com \\ Aldefa Lingga \\ Teknologi Informasi \\ Politeknik Negeri Jember \\ Jember, Indonesia \\ aldefalingga@gmail.com
}

\author{
Nurul Dwi Zainita \\ Teknologi Informasi \\ Politeknik Negeri Jember \\ Jember, Indonesia \\ n.zainita68@gmail.com \\ Muhammad Fendrik Nurul Jadid \\ Teknologi Informasi \\ Politeknik Negeri Jember \\ Jember, Indonesia \\ fendrik1311@gmail.com \\ Trismayanti Dwi Puspitasari \\ Teknologi Informasi \\ Politeknik Negeri Jember \\ Jember, Indonesia \\ trismayanti@polije.ac.id
}

\author{
Rifrinda Afianti Magfiroh \\ Teknologi Informasi \\ Politeknik Negeri Jember \\ Jember, Indonesia \\ nengrifrinda@gmail.com \\ Zavira Wahyu Dewi Pratiwi \\ Teknologi Informasi \\ Politeknik Negeri Jember \\ Jember, Indonesia \\ wahyuzavira@gmail.com
}

\begin{abstract}
Quality of broiler feed impact on meat quality produced. If feeding broiler unstandardized so broiler will be non-optimal condition such as lack of appetite an energy, susceptible to disease. Even consequences can lead to death on the broiler. To minimize the mortality in broiler then used to genetic algorithm as combination of chicken feed with an optimal output for the benefit. The advantage of using a genetic algorithm is seen from its ability to find a good solution. The advantages of genetic algorithms when compared to other algorithms are the less mathematical calculation process. This algorithm will look for solutions without regard to processes related to problems that are solved directly. This study will design the optimization of the best combination of feed in Broiler chickens according to the appropriate price using the genetic algorithm method. From the results of research conducted obtained at the best generation to generation 17 with the best fitness value is 0.0792 and the smallest fitness value is 0.0412 with average fitness obtained is 0.05829.
\end{abstract}

Keywords-broiler; genetic algorithms.

Abstrak - Kualitas pakan broiler berdampak pada kualitas daging yang dihasilkan. Jika memberi makan ayam pedaging tidak terstandar maka kondisi ayam pedaging akan menjadi tidak optimal seperti kurang nafsu makan dan energi, rentan terhadap penyakit. Bahkan bisa mengakibatkan kematian pada ayam pedaging. Untuk untuk meminimalisir kematian pada ayam pedaging maka penelitian ini akan dianalisis dengan algoritma genetika sehingga memberikan manfaat dalam pemberian kombinasi pakan ayam dengan hasil yang optimal. Keuntungan menggunakan algoritma genetika dilihat dari kemampuannya menemukan solusi yang baik. Kelebihan dari algoritma genetika jika dibandingkan dengan algoritma lainnya adalah proses perhitungan matematisnya kurang. Algoritma ini akan mencari solusi tanpa memperhatikan proses yang terkait dengan masalah yang diselesaikan secara langsung. Penelitian ini akan merancang optimasi kombinasi pakan terbaik pada ayam Broiler sesuai dengan harga yang sesuai menggunakan metode algoritma genetika. Dari hasil penelitian yang dilakukan diperoleh generasi terbaik sampai generasi 17 dengan nilai fitness adalah 0,0792 dan nilai fitness terkecil adalah 0,0412 dengan rata-rata fitness yang diperoleh adalah 0,05829 .

Keywords-broiler; algoritma genetika.

\section{PENDAHULUAN}

Peternakan ayam Broiler merupakan salah satu jenis ternak unggas yang bernilai ekonomis dan menghasilkan produk berupa daging. Selain karena permintaan kebutuhan konsumsi daging ayam yang besar, faktor ekonomi juga merupakan faktor yang mendorong beberapa masyarakat untuk mencoba bisnis ini [1]. Ada 252.198.032 populasi ternak ayam Broiler di provinsi Jawa Timur dimana populasi ternak ayam Broiler paling tinggi diantara populasi ternak unggas lainnya [2].

Daging ayam Broiler merupakan salah satu sumber protein hewani yang dibutuhkan oleh manusia. Pakan merupakan faktor paling penting dalam usaha peternakan, hal ini sangat mempengaruhi tinggi rendahnya suatu produksi. Oleh sebab itu, kualitas pakan ayam Broiler sangat mempengaruhi kualitas daging yang dihasilkan. Jika penentuan pakan yang diberikan tidak sesuai dengan standarisasi kebutuhan ayam maka yang terjadi adalah ayam Broiler tidak mencapai kondisi yang optimal seperti kurangnya nafsu makan, mudah terserang penyakit, dan tidak lincah. Bahkan yang lebih fatal lagi bisa mengakibatkan kematian pada ayam tersebut.

Dikutip dari jurnal Penentuan Komposisi Pakan Ternak Untuk Memenuhi Nutrisi Ayam Petelur Dengan Biaya Minimum Menggunakan Pearson Square (PS) milik Aniffudin Faisal Reza, Hasil akurasi dari perhitungan 
komposisi ransum dengan menggunakan algoritma Pearson Square (PS) didapat akurasi mix komposisi bahan pakan sebesar $100 \%$. Setiap prosentase mix bahan pakan akan dikonversi kedalam kilogram $(\mathrm{kg})$ yang jika dijumlahkan akan menghasilkan jumlah kebutuhan ransum sesuai yang diinginkan [3].

Pada jurnal lainnya yang berjudul Penerapan Algoritma Genetika Pada Permasalahan Fuzzy Linear Programming Untuk Formulasi Ransum Unggas milik Siska Dwi Lestari mengatakan bahwa formulasi ransum dengan Linear Programming (LP) menghasilkan harga yang lebih tinggi. Dengan menggunakan fuzzy linear programming (FLP) yang diperkenalkan Adrizal dan Marimin (2004) formulasi ransum yang dihasilkan lebih murah dibandingkan metode LP. Ternyata dengan menggunakan Algoritma Genetika menghasilkan formulasi ransum yang lebih murah dibandingkan FLP [4].

Untuk meminimalisir terjadinya kematian pada ayam akibat dari pemberian pakan yang tidak optimal maka digunakanlah algoritma genetika sebagai penentu kombinasi pakan ayam dengan output takaran yang optimal. Pemilihan pakan yang berkualitas tentunya akan meningkatkan keuntungan peternak karena biaya pakan akan semakin efisien sebagai dampak konversi pakan yang baik, waktu yang lebih singkat karena pertumbuhan ayam yang cepat, dan sehat karena mendapatkan nutrisi yang seimbang.

Algoritma genetika merupakan suatu algoritma yang diinspirasi dari teori evolusi yang kemudian diadopsi menjadi algoritma komputasi untuk mencari solusi dengan cara yang lebih alamiah. Keuntungan penggunaan algoritma genetika sangat jelas terlihat dari kemudahan implementasi dan kemampuannya untuk menemukan solusi yang bagus (bisa diterima) secara cepat [5]. Beberapa kelebihan algoritma genetika jika dibandingkan dengan algoritma pencarian lainnya adalah Algoritma ini hanya melakukan sedikit perhitungan matematis yang berhubungan dengan masalah yang ingin diselesaikan. Karena sifat perubahan evolusi alamiah, maka algoritma ini akan mencari penyelesaian tanpa memperhatikan proses-proses yang berhubungan dengan masalah yang diselesaikan secara langsung. Algoritma ini juga dapat mengendalikan fungsi objektif dan batasan yang didefinisikan, baik pada ruang pencarian diskrit atau ruang pencarian analog. Operatoroperator evolusi membuat algoritma ini sangat efektif pada pencarian global. Algoritma ini memiliki fleksibilitas yang tinggi untuk dihibridkan dengan metode pencarian lainnya agar lebih efektif. Kelemahan algoritma genetika jika dibandingkan dengan algoritma pencarian lainnya adalah adanya ketidakpastian untuk menghasilkan solusi optimum global, karena sebagian besar dari algoritma ini berhubungan dengan bilangan random yang bersifat probabilistik [6].

Algoritma genetika yang dikembangkan oleh Goldberg adalah algoritma komputasi yang diinspirasi teori evolusi Darwin yang menyatakan bahwa kelangsungan hidup suatu makhluk dipengaruhi aturan "yang kuat adalah yang menang". Darwin juga menyatakan bahwa kelangsungan hidup suatu makhluk dapat dipertahankan melalui proses reproduksi, crossover, dan mutasi[7].

Proses pencarian solusi diawali dengan tahap pembangkitan populasi awal secara acak. Populasi ini terdiri dari kromosom-kromosom. Setiap kromosom merupakan gambaran solusi atas pemecahan masalah. Populasi yang telah dipilih tersebut akan menghasilkan keturunan baru yang sifatnya diharapkan lebih baik dari populasi sebelumnya. Populasi yang baik sifatnya akan memiliki peluang untuk terus dikembangkan agar menghasilkan keturunan populasi yang lebih baik selanjutnya. Dengan demikian, solusi terbaik yang diinginkan dapat dicapai dengan terus mengulang proses pencarian keturunan[8].

Populasi ini terdiri dari kromosom-kromosom. Setiap kromosom merupakan gambaran solusi atas pemecahan masalah. Populasi yang telah dipilih tersebut akan menghasilkan keturunan baru yang sifatnya diharapkan lebih baik dari populasi sebelumnya. Populasi yang baik sifatnya akan memiliki peluang untuk terus dikembangkan agar menghasilkan keturunan populasi yang lebih baik selanjutnya. Dengan demikian, solusi terbaik yang diinginkan dapat dicapai dengan terus mengulang proses pencarian keturunan. Dalam proses tersebut, sebelum algoritma genetika dijalankan didefinisikan suatu fungsi fitness yang menyatakan tingkat keberhasilan sebuah populasi. Dengan melakukan perhitungan berdasarkan fungsi fitness, akan dapat ditentukan populasi yang akan dipertahankan untuk menghasilkan generasi selanjutnya. Proses ini biasa disebut sebagai proses seleksi. Proses ini merupakan salah satu tahap yang dirangkai dalam proses yang iterative [9].

Pengkodean (Encoding) adalah proses perubahan karakter data yang akan dikirim dari suatu titik ke titik lain dengan kode yang dikenal oleh setiap termianal yang ada, dan menjadikan setiap karakter data dalam sebuah informasi digital ke dalam bentuk biner agar dapat ditransmisikan. Suatu terminal yang berbeda menggunakan kode biner yang berbeda untuk mewakili setiap karakter.

Tujuan dari Pengkodean (Encoding) adalah menjadikan setiap karakter data dalam sebuah informasi digital ke dalam bentuk biner agar dapat ditransmisikan dan bisa melakukan komunikasi data. Kode-kode yang digunakan dalam komunikasi data pada system computer memiliki perbedaan dari generasi ke generasinya, karena semakin besar dan kompleksnya data yang akan dikirim / digunakan. Dalam penyaluran data antar komputer, data yang disalurkan harus dimengerti oleh masing-masing perangkat baik oleh pengirim maupun penerima. Untuk itu digunakan system sandi sesuai standard. Suatu karakter didefinisikan sebagai huruf, angka, tanda aritmetik dan tanda khusus lainnya [10].

Pada tulisan ini dibuatlah sebuah sistem informasi optimasi pencampuran pakan pada ayam Broiler menggunakan metode algoritma genetika. Sistem informasi ini dapat memberikan informasi pada peternak mengenai kombinasi pakan yang sesuai dengan standarisasi kebutuhan ayam Broiler sesuai hasil yang didapat.

\section{METODE}

\section{A. Flowchart System}

Metode penelitian yang di gunakan adalah sesuai dengan proses manual Gentetika algoritma. 


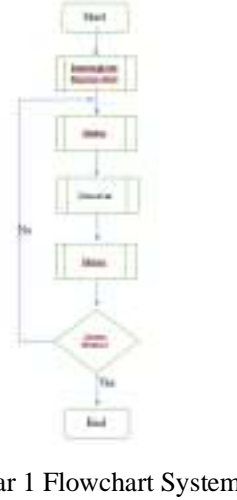

Populasi awal terdiri dari bebrapa kromosom. Kromosom tersebut terdiri dari beberapa gen dimana gen tersebut adalah encoding yang akan digunakan untuk mempresentasikan masalah tersebut. Teknik yang digunakan dalam permasalahan ini adalah encoding binary. Pada binary encoding, setiap bahan makanan di wakilkan oleh sebuah angka binary 0 dan 1 , dimana angka tersebut menggambarkan gen pada sebuah kromosom. Setiap gen di wakilkan oleh binary 4 bit, yang menyatakan bahwa harus ada bahan makanan yang teilih dari 15 bahan makanan yang tersedia. Setiap kromosom yang ada pada suatu generasi menggambarkan bahan makanan yang digunakan untuk mendapatkan hasil optimal dalam pemenuhan nutrisi ayam broiler agar bisa mendapatkan daging yang optimal namun pengeluaran yang sangat optimal untuk para peternak, dan kromosom yang mewakili solusi tersebut adalah harus memenuhi 2 jenis makanan dalam sehari yaitu mempresentasikan pakan di pagi hari dan sore hari.Pertama, pastikan bahwa Author memiliki template yang benar. Template ini dirancang untuk ukuran kertas A4. Jika Author menggunakan kertas dengan ukuran lain, maka seseuaikan dengan ukuran kertas yang telah ditentukan yaitu ukuran kertas A4.

\section{B. Tahapan Metode}

Berdasarkan flowchart system yang akan diterapkan beberapa langkah yang harus dilakukan adalah sebagai berikut:

1. Pembangkitan Populasi Awal: Populasi awal merupakan kumpulan dari bebrapa kromosom. Langkah awal yang harus di bentuk adalah membangkitkan populasi awal. Populasi awal di bentuk dengan cara membangkitkan sebuah bilangan acak dari 1 sampai dengan jumlah data pakan yang ingin di kombinasikan dalam sehari

2. Seleksi: Metode seleksi yang dipilih adalah roulette well selection . Dengan metode ini, setiap kromosom akan di bandingkan dengan bilangan acak yang di bangkitkan sebanyak jumlah dari kromosom yang ada. Setelah di bandingkan maka akan terbentuk susunan kromosom baru sebuah generasi.

3. Crossover: Crossover adalah sebuah proses untuk menyilangkan kedua kromosom sehingga di dapatkan suatu kromosom baru yang mirip dengan kromosom induknya. Proses crossover di lakukan untuk mencari kromosom terbaik untuk proses selanjutnya, yaitu dengan cara menggantikan kromosom yang tidak pantas di pertahankan dengan kromosom baru yang lebih baik daripada induknya. Banyaknya kromosom yang akan di crossover adalah sesuai dengan probabilitas yang telah di terapkan yaitu 0,10 dan 0,05 . Pemilihan gen yang akan di-crossover dilakukan berdasarkan probabilitas crossover. Nilai probabilitas crossover tersebut di kalikan dengan jumlah kromosom yang ada. Langkah selanjutnya adalah membangkitkan nilai acak sebanyak jumlah kromosom. Apabila nilai kurang dari nilai probablitas crossover maka pada kromosom yang bersesuaian akan di lakukan crossover. Pada aplikasi ini crossover yang digunakan adalah discrete crossover. Pada teknik ini, akan digunakan dua buah kromosom untuk membuat kromosom baru . untuk membuatnya kromosom induk di pecahnya menjadi lima bagian yang berbeda. Setelah itu bilangan acak akan di bangkitkan sebanyak lima buah. Bilangan satu menyatakan induk, dan bilangan kedua menyatakan induk yang kedua. Dan kromosom yang baru dibentuk di sesuaikan dengan bilangan acak yang telah di sesuaikan.

4. Mutasi: Proses mutasi adalah proses dimana suatu gen akan mengalami penyimpangan dari kromosom induknya. Banyaknya jumlah yang akan di simpangkan adalah sebanyak nilai probabilitas yang sebelumnya sudah di tentukan.

\section{HASIL DAN PEMBAHASAN}

Proses penyelesaian dengan menggunakan metode algortima untuk penentuan komposisi makanan ayam broiler dengan parameter standar kebutuhan nutrisi dan harga adalah sebagai berikut.

\section{A. Proses Encoding}

Berikut aladah jenis makanan yang akan jadikan pakan ayam boiler beserta kandungan kkal per 20 gr dan harga per 20 gr sesuai dengan jumlah takaran yang akan diberikan per satu ayam boiler.

TABEL I JENIS PAKAN AYAM BROILER

\begin{tabular}{|c|c|c|c|c|c|}
\hline No & $\begin{array}{c}\text { Jenis } \\
\text { Makanan }\end{array}$ & $\begin{array}{c}\text { Energi } \\
\text { kkal / 100 } \\
\text { gr }\end{array}$ & $\begin{array}{c}\text { Energ } \\
\text { i kkal } \\
\text { / } 20 \text { gr } \\
\end{array}$ & Harga/kg & $\begin{array}{c}\text { Harga/20g } \\
\text { r }\end{array}$ \\
\hline 1 & Jagung & 860 & 172 & 5.200 & 104 \\
\hline 2 & $\begin{array}{c}\text { Kacang } \\
\text { hijau }\end{array}$ & 345 & 69 & 21.600 & 432 \\
\hline 4 & $\begin{array}{l}\text { Kacang } \\
\text { kedelai }\end{array}$ & 380 & 76.2 & 7500 & 150 \\
\hline 5 & $\begin{array}{c}\text { Kacang } \\
\text { bude }\end{array}$ & 336 & 67.2 & 50000 & 1000 \\
\hline 6 & Susu bubuk & 122 & 24.4 & 10000 & 200 \\
\hline 7 & Biji kecipir & 405 & 81 & 50000 & 1000 \\
\hline 8 & $\begin{array}{c}\text { Bungkil } \\
\text { kelapa }\end{array}$ & 368 & 73.6 & 4000 & 80 \\
\hline 9 & Sorgum & 329 & 65.8 & 5000 & 100 \\
\hline 10 & $\begin{array}{c}\text { Bungkil } \\
\text { kacang } \\
\text { tanah }\end{array}$ & 336 & 67.2 & 2400 & 48 \\
\hline 11 & $\begin{array}{c}\text { Tepung } \\
\text { ikan }\end{array}$ & 316 & 63.2 & 10500 & 210 \\
\hline 12 & Gandum & 327 & 65.4 & 55000 & 1100 \\
\hline 13 & Bekatul & 275 & 55 & 4000 & 80 \\
\hline 14 & $\begin{array}{l}\text { Tepung } \\
\text { Gaplek }\end{array}$ & 363 & 72.6 & 2800 & 56 \\
\hline \multirow[t]{2}{*}{15} & $\begin{array}{l}\text { Tepung } \\
\text { Daun } \\
\text { Pepaya }\end{array}$ & 79 & 15,8 & 6800 & 136 \\
\hline & & & & 252800 & 5056 \\
\hline
\end{tabular}


Untuk selanjutnya setiap makanan akan dikodekan dengan menggunakan binary string yang memperesentasikan nomor jenis makanan sesuai dengan tabel daftae jenis makanan. Panjang string yang digunakan untuk setiap gen adalah 4 bit dengan asumsi jumlah jenis makanan yang dapat diberikan adalah sebanyak 15 jenis. Berikut adalah contoh dari struktur kromosom

TABEL II GENOTIPE DAN FENOTIPE

\begin{tabular}{|l|l|l|}
\hline & Makan Pagi & Makan Sore \\
\hline Genotipe & 0011 & 0110 \\
\hline Fenotipe & 3 & 6 \\
\hline
\end{tabular}

\section{B. Nilai Fitness}

Suatu individu di evaluasi oleh sebuah fitnes sebagai ukuran ketahanan dari individu tersebut. Karena bertujuan untuk mendapatkan kalori penuh dengan biaya maksimal untuk pakan yaitu sebesar .500 per hari untuk satu ayam maka fungsi fitnes yang digunakan adalah :

$f= \begin{cases}\sum_{\text {bi.ki }} & \text { jika } \sum \text { bi.ki } \leq 500 \\ \sum_{\text {bi.ki }-\frac{\left(\sum \text { bi.ki }-500\right)}{10}} & j i k a \sum_{\text {bi.ki }>500}\end{cases}$

$k_{i}=$ Kalori tiap jenis pakan

$b_{i}=$ Bernilai 1 jika suatu jenis pakan teilih dan bernilai 0 jika tidak teilihc $c_{i}=$ Harga tiap jenis pakan

\section{Pembangkitan populasi awal}

Pembangkitan populasi awal dilakukan dengan membangkitkan individu sebanyak 21 individu. Berikut contoh invidu yang telah dibangkitkan sebagai populasi awal.

\begin{tabular}{|l|l|l|l|l|l|l|l|}
\hline Hari & Pagi & Sore & Kalori & Harga & $\begin{array}{l}\text { Fitne } \\
\text { s }\end{array}$ & $\begin{array}{l}\text { pro- } \\
\text { fitnes }\end{array}$ & $\begin{array}{l}\text { fitnes } \\
\text { kumu } \\
\text { latif }\end{array}$ \\
\hline 1 & 1101 & 0101 & & & & & \\
\hline & 13 & 5 & 122 & 1050 & 67 & 0.0264 & $\begin{array}{l}0.026 \\
4\end{array}$ \\
\hline 2 & 0110 & 1010 & & & & & \\
\hline & 6 & 10 & 91 & .248 & 91 & 0.0359 & 0.062 \\
& & & & & & & 3 \\
\hline$\ldots$. & $\ldots .$. & $\ldots$. & $\ldots$. & $\ldots$ & $\ldots$ & $\ldots$ & \\
\hline$\ldots$. & $\ldots$. & $\ldots$ & $\ldots$ & $\ldots$ & $\ldots$. & $\ldots$. & $\ldots$ \\
\hline 20 & 0111 & 0101 & & & & & \\
\hline & 7 & 4 & 157 & .1 .150 & 92 & 0.0363 & 0.941 \\
\hline 21 & 0101 & 1000 & & & & & \\
\hline & 4 & 8 & 149 & .230 & 149 & 0.0587 & 1.000 \\
\hline & & & & & 2537 & 1.000 & \\
\hline
\end{tabular}

\section{Proses Seleksi}

Proses seleksi roulette well selection yaitu dengan memilih salah satu individu dengan nilai fitness yang sudah diberi skala dengan tujuan menghindari kecenderungan terjadi konvergen. Dari proses seleksi yang dilakukan individu no 18 yang teilih, maka individu ke 18 pindah ke posisi pertama.

\section{E. Proses Regenerasi}

1. Crossover yaitu proses yang dilakukan untuk mendapatkan individu baru yang lebih baik. Karena nilai probabilitas crossover adalah 0,10 maka diharapkan $10 \%$ dari total kromosom yang ada akan mengalami proses crossover minimal $10 \% * 21=2$ atau 2 dari 21 invidu akan mengalami crossover. Proses crossover yang dilakukan dengan invidu yang teilih yaitu individu ke 15 dan ke 18 .

TABEL IV PROSES CROSSOVER
\begin{tabular}{|l|l|l|l|}
\hline 15 & 1011 & 1000 & induk 1 \\
\hline 18 & 0011 & 0101 & induk 2 \\
\hline $\mathrm{x}$ & 1011 & 0101 & anak 1 \\
\hline $\mathrm{x}$ & 0011 & 1000 & anak 2 \\
\hline
\end{tabular}

2. Mutasi dilakukan dengan menukar gen di tiap individu, langkah-langkah yang perlu dilakukan dalam proses mutasi yatu :

a. Mengitung jumlah bit yang ada dalam populasi dan kalikan dengan jumlah popize $8 * 21=168$

b. Paramater peluang mutasi $=0,5$ maka diharapkan $5 \%$ dari total bit yang ada dapat mengalami proses mutasi yaitu $5 \% * 168=8$ atau 8 diharapkan minimal ada 8 bit yang mengalami proses mutasi dari total keseluruhan 168 bit

Proses mutasi dilakukan dengan membangkitkan bilangan acak dan mengganti nilai bit yang ada sesuai dengan bilangan acak yang ada.Contoh mutasi yang dilakukan

TABEL V MUTASI
\begin{tabular}{|l|l|l|}
\hline 12 & 1011 & 0111 \\
\hline sesudah mutasi & 1111 & 0011 \\
\hline 13 & 1110 & 0110 \\
\hline sesudah mutasi & 1010 & 1110 \\
\hline
\end{tabular}

\section{F.Tahap Pengulangan}

Individu baru hasil proses crossover dan mutasi digunakan untuk menggantikan induknya kemudian dipakai kembali untuk membentuk generesai berikutnya sampai didapat generi terbaik sesuai dengan yang diharapkan

\section{G.Hasil Akhir}

Dari hasil penelitian yang dilakukan generasi terbaik didapatkan pada generasi ke 17 dengan nilai fitnes terbaik yaitu 0.0792 dan nilai fitnes terkecilnya yaitu 0.0412 dengan rata fitness yang didapat yaitu 0.05829 .

\section{KESIMPULAN}

Algoritma genetika dapat diterapakan untuk optimasi komposisi pakan ayam broiler sesuai standarisasi kebutuhan nutrisi. Dengan 21 pembangkitan individu dapat disimpulan bahwa generasi ke 17 memiliki nilai fitness terbaik untuk ayam boiler yang masih proses pertumbuhan dari umur $0-$ 3 minggu atau 21 hari. Hal ini menunjukkan bahwa pada generasi tersebut menghasilkan individu yang lebih baik dibandingkan dengan individu lainnya. Maka didapatkan optimasi komposisi terbaik pada kromosom 12 dan 13. Dengan nilai fitness adalah 0,0792 dan nilai fitness terkecil adalah 0,0412 dengan rata-rata fitness yang diperoleh adalah 0,05829 . 


\section{PENGHARGAAN}

Ucapan terima kasih kami ucapkan kepada bapak/ibu dosen pengampu mata kuliah workshop sistem cerdas serta kepada pihak Politeknik Negeri Jember atas kesediannya memberi petunjuk, dorongan dan membantu menyelesaikan riset ini.

\section{REFERENSI}

[1] Muchammad Sholihin Bachtiar . "Ternak Ayam Potong di Daerah Jember oleh Muchammad SholihinBachtiar Halaman all Kompasiana.com." [Daring]. Tersedia pada: https://www.kompasiana.com/sholihinbachtiar/5c63b8b212ae9433267 7c412/ternak-ayam-potong-di-daerah-jember?page=all. [Diakses: 09. Mei-2019].

[2]“BPS Provinsi Jawa Timur." [Daring]. Tersedia pada: https://jatim.bps.go.id/statictable/2018/01/31/794/populasi-ternakunggas-menurut-kabupaten-kota-di-jawa-timur-2016-ekor-.html. [Diakses: 09-Mei-2019].

[3] A. F. Reza, "PENENTUAN KOMPOSISI PAKAN TERNAK UNTUK MEMENUHI KEBUTUHAN NUTRISI AYAM PETELUR DENGAN BIAYA MINIMUM MENGGUNAKAN Pearson Square (PS)," hlm. 9.

[4] A. Aribowo, S. Lukas, dan M. Gunawan, "PENERAPAN ALGORITMA GENETIKA PADA PENENTUAN KOMPOSISI PAKAN AYAM PETELUR," hlm. 4, 2008.
[5] Firman Arifin."Algoritma Genetika dan Contoh Aplikasinya www.firman-its.com." [Daring]. Tersedia pada: https://www.firmanits.com/2007/05/17/algoritma-genetika-dan-contoh-aplikasinya/. [Diakses: 09-Mei-2019].

[6] Yakhdi Perari Pinem."Implementasi Algoritma Genetik Dalam Penjadwalan Perkuliahan dan Praktikum (Studi Kasus : Fasilkom-TI dan FMIPA USU) | 123dok document." [Daring]. Tersedia pada: https://id.123dok.com/document/oy816wzr-implementasi-algoritmagenetik-dalam-penjadwalan-perkuliahan-dan-praktikum-studi-kasusfasilkom-ti-dan-fmipa-usu.html. [Diakses: 09-Mei-2019].

[7 ]D. Hermawanto, "Algoritma Genetika dan Contoh Aplikasinya," hlm. 10 .

[8] Arnold Aribowo Samuel Lukas dan Martin Gunawan, "PENERAPAN ALGORITMA GENETIKA PADA PENENTUAN KOMPOSISI PAKAN AYAM PETELUR," Yogyakarta, 21 Juni 2008.

[9] I. D. M. A. B. J. Vivine Nurcahyawati, "PENENTUAN JARAK TERPENDEK PADA JALUR DISTRIBUSI BARANG DI PULAU JAWA DENGAN MENGGUNAKAN ALGORITMA GENETIKA," vol. Volume 1, Nomor 3, Desember 2012.

[10] Dwi Setiyo.“(PDF) Makalah Komunikasi Data - Teknik Encoding.pdf l dwi setiyo - Academia.edu." [Daring]. Tersedia pada:https://www.academia.edu/20025141/Makalah_Komunikasi_Dat a_-_Teknik_Encoding.pdf. [Diakses: 09-Mei-2019]. 